\title{
Correction to: METTL14 promotes glomerular endothelial cell injury and diabetic nephropathy via m6A modification of a-klotho
}

Manna Li, Le Deng and Gaosi Xu* (1)

\section{Correction to: Mol Med (2021) 27:106}

https://doi.org/10.1186/s10020-021-00365-5

Following publication of the original article ( $\mathrm{Li}$ et al. 2021), the authors identified an error in Fig. 2. The correct Fig. 2 is given in this erratum.

The original article has been corrected. 


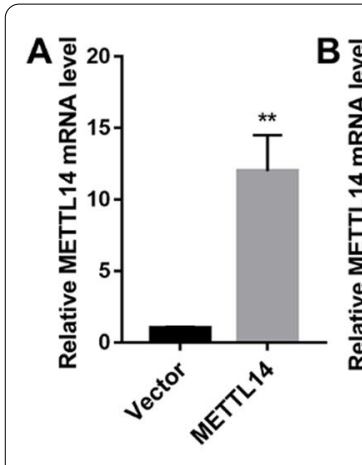

E

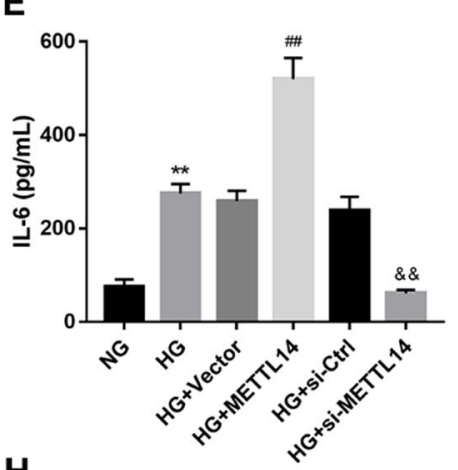

H

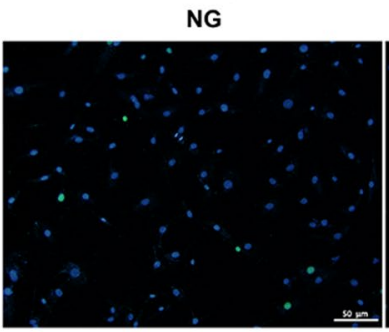

HG+ METTL14

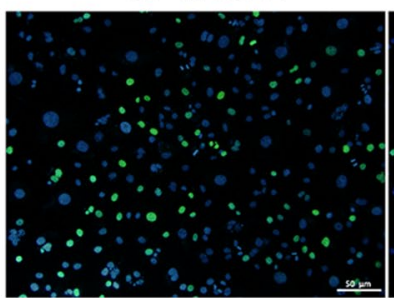

C

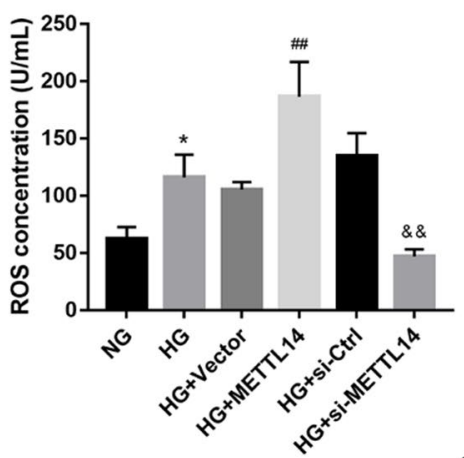

$F$

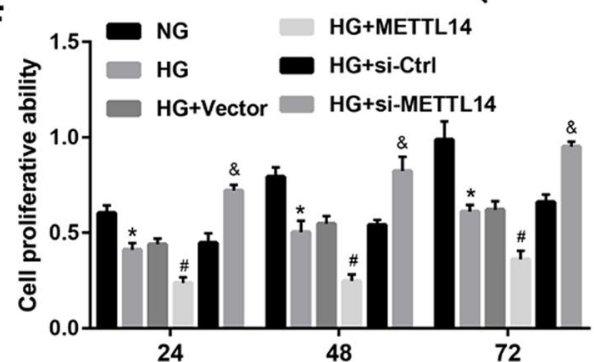

HG

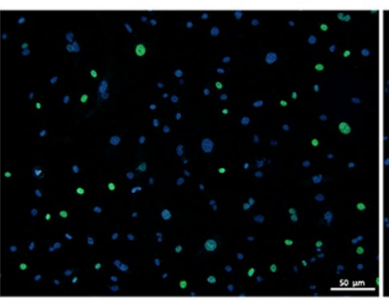

HG+si-Ctrl

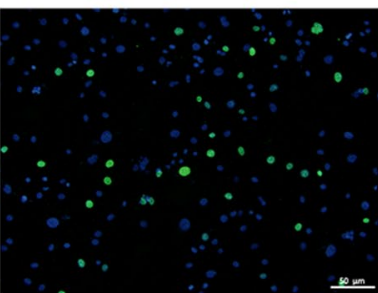

HG+Vector

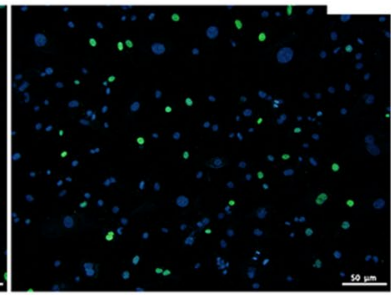

HG+si-METTL14

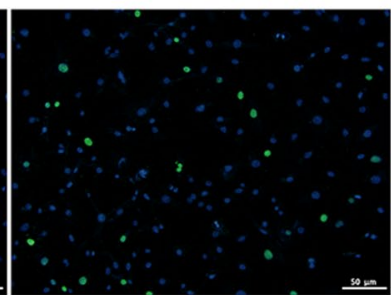

D

G

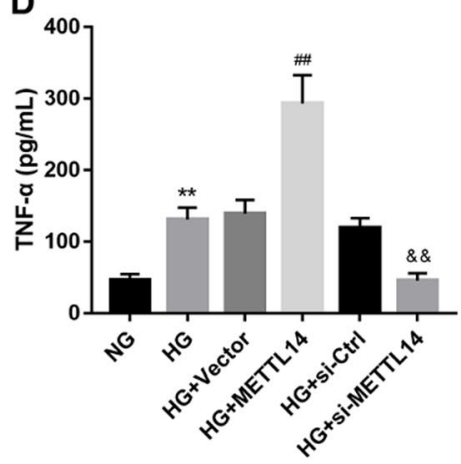

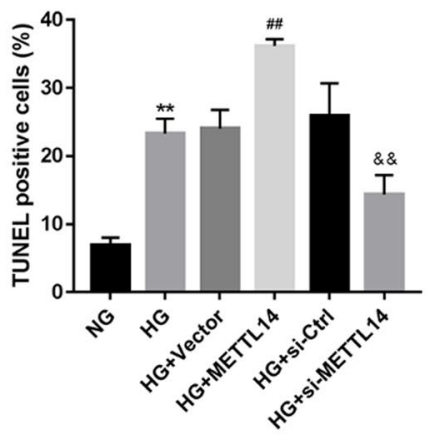

Fig. 2 METTL14 promoted high glucose-induced glomerular endothelial cell injury. A Expression of METTL14 was examined by qRT-PCR after transfected with Vector or MELLT14 plasmid. ${ }^{* *} \mathrm{P}<0.01$ vs. Vector. B Expression of METTL14 was examined by qRT-PCR after transfected with si-ctrl or MELLT14 siRNA. ${ }^{* *} P<0.01$ vs. si-Ctrl. C-E The levels of ROS, TNF-a and IL-6 were detected by ELISA. F Cell proliferation was assessed by CCK-8. G, H Cell apoptosis was analysed by TUNEL staining, Scale bar: $50 \mu \mathrm{m}$. ${ }^{*} \mathrm{P}<0.05,{ }^{*} \mathrm{P}<0.01 \mathrm{vs}$. NG; ${ }^{\#} \mathrm{P}<0.05,{ }^{\# \#} \mathrm{P}<0.01 \mathrm{Vs}$. HG + Vector; ${ }^{\&} \mathrm{P}<0.05$, \&\&P $<0.01$ vs. $H G+$ si-Ctrl. Data are presented as the mean $\pm S D(n=3)$

Published online: 24 January 2022

\section{Reference}

Li M, Deng L, Xu G. METTL14 promotes glomerular endothelial cell injury and diabetic nephropathy via m6A modification of a-klotho. Mol Med. 2021;27:106. https://doi.org/10.1186/s10020-021-00365-5.

\section{Publisher's Note}

Springer Nature remains neutral with regard to jurisdictional claims in published maps and institutional affiliations. 